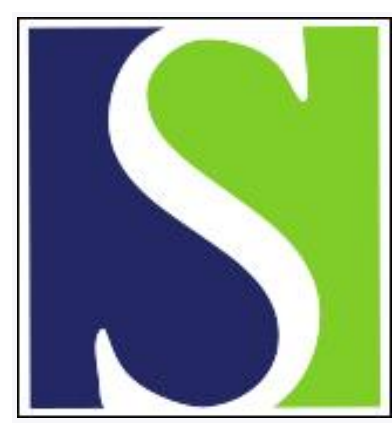

Scand J Work Environ Health 1992;18(2):101-104

https://doi.org/10.5271/sjweh.1605

Issue date: 01 Apr 1992

Effect of occupational exposure to cobalt blue dyes on the thyroid volume and function of female plate painters.

by Prescott E, Netterstrom B, Faber J, Hegedus L, Suadicani P, Christensen JM

Affiliation: Clinic of Occupational Medicine, University Hospital of Copenhagen, Denmark.

This article in PubMed: www.ncbi.nlm.nih.gov/pubmed/1604269

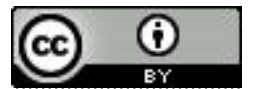




\title{
Effect of occupational exposure to cobalt blue dyes on the thyroid volume and function of female plate painters
}

\author{
by Eva Prescott, MD, ${ }^{1}$ Bo Netterstrøm, MD,${ }^{1}$ Jens Faber, DrMedSc, ${ }^{2,3}$ Laszlo Hegedüs, DrMedSc, ${ }^{2}$ \\ Poul Suadicani, OD, ${ }^{1}$ Jytte M Christensen, MSc, ${ }^{4}$
}

\begin{abstract}
PRESCOTT E, NETTERSTRØM B, FABER J, HEGEDÜS L, SUADICANI P, CHRISTENSEN JM. Effect of occupational exposure to cobalt blue dyes on the thyroid volume and function of female plate painters. Scand J Work Environ Health 1992;18:101-4. It has previously been shown that long-term oral exposure to cobalt can cause goiter and myxedema. The effect of industrial cobalt exposure on thyroid volume and function was determined for 61 female plate painters exposed to cobalt blue dyes in two Danish porcelain factories and 48 unexposed referents. Thyroid volume was determined by ultrasonography. The cobalt blue dyes were used in one of two forms, cobalt aluminate (insoluble) and cobalt-zinc silicate (semisoluble). Only the subjects exposed to semisoluble cobalt had a significantly increased urinary cobalt content $\left(1.17 \mu \mathrm{g} \cdot \mathrm{mmol}^{-1}\right.$ versus $\left.0.13 \mu \mathrm{g} \cdot \mathrm{mmol}^{-1}, \mathrm{P}<0.0001\right)$. These subjects also had increased levels of serum thyroxine $\left(\mathrm{T}_{4}\right)$ and free thyroxine $\left(\mathrm{FT}_{4} \mathrm{I}\right)(\mathrm{P}=0.0001$ and 0.0029 , respectively), unaltered serum thyroid stimulating hormone (TSH), and marginally reduced 3,5,3'-triiodothyronine $\left(\mathrm{T}_{3}\right)$, whereas thyroid volume tended to be lower $(\mathrm{P}=0.14)$. The group exposed to insoluble cobalt did not differ significantly in any thyroid-related parameters. No correlation between urinary cobalt and $\mathrm{FT}_{4} \mathrm{I}$ or thyroid volume was found. The study demonstrates an effect of cobalt on thyroid hormone metabolism.
\end{abstract}

Key terms: cross-sectional study, goiter, plate painting, porcelain factory, thyroid hormones, ultrasound.

Cobalt is known to affect the thyroid gland, presumably by inhibiting the uptake and maybe also the organification of iodine $(1,2)$. This effect of cobalt can lead to the formation of a goiter.

Cobaltous chloride used in oral doses of $2-4 \mathrm{mg}$. $\mathrm{kg}^{-1} \cdot \mathrm{d}^{-1}$ to treat children suffering from anemia has been reported to cause goiter, and in some individuals also myxedema, if administered for several months (1-5). Furthermore, cobalt has been used successfully preoperatively in the treatment of hyperthyroidism $(6,7)$. Adverse health effects on the thyroid gland of industrial workers exposed to cobalt have not previously been described in the literature. While conducting an investigation into the health of cobalt-exposed plate painters at two Danish porcelain factories, we have therefore examined the effect of long-term cobalt exposure on thyroid volume and function.

\section{Subjects and methods}

The study took place from May to July 1988 and was a cross-sectional study of the female plate painters in

\footnotetext{
' Clinic of Occupational Medicine, University Hospital of Copenhagen, Denmark.

2 Medical Department F, Herlev University Hospital, Herlev, Denmark.

${ }^{3}$ Medical Department E, Frederiksberg Hospital, Frederiksberg, Denmark.

4 Danish National Institute of Occupational Health, Copenhagen, Denmark.
}

Correspondence to: Dr E Prescott, Ole Suhrs Gade 23, 4.tv, DK-1354 Copenhagen K, Denmark. two Danish porcelain factories with a reference group consisting of women working at the same factories.

The chemicals to which the plate painters were mainly exposed were cobalt blue dyes. At one of the two factories cobalt was used in an insoluble form, cobalt aluminate, whereas cobalt-zinc silicate, which is semisoluble, was used at the other factory.

These factories produce porcelain plates by the special technique of underglazing (with cobalt blue color) especially developed to withstand the intense heat of the second porcelain firing. Each plate is spray-painted two or three times with the water-based cobalt-blue underglaze. After each painting procedure, the plates are allowed to dry, and the excess color is removed with a brush. The plate painting is carried out in a fume extraction cupboard.

Hygienic measurements in 1987-1988 showed cobalt concentrations around $0.05 \mathrm{mg} \cdot \mathrm{m}^{-3}$ in the workplaces.

The subjects consisted of 36 plate painters from the first factory (exposed I - using cobalt aluminate), 25 plate painters from the second factory (exposed II - using cobalt-zinc silicate), and a reference group consisting of 48 age-matched women (referents), 34 from the first factory and 14 from the second. The reference group had never been occupationally exposed to cobalt.

All of the participants filled out a questionnaire concerning their own health and genetic disposition with special regard to thyroid disease; use of medicine, including oral contraceptives, vitamins and herbal medicines with special regard to iodine content; day of menstrual cycle (1 through 28 , postmenopausal women 
Table 1. Characteristics of the plate painters and the referents.

\begin{tabular}{|c|c|c|c|c|c|c|c|c|c|}
\hline \multirow[t]{2}{*}{ Group } & \multicolumn{2}{|c|}{$\begin{array}{c}\text { Age } \\
\text { (years) }\end{array}$} & \multicolumn{2}{|c|}{$\begin{array}{l}\text { Length of } \\
\text { employment } \\
\text { (years) }\end{array}$} & \multicolumn{2}{|c|}{$\begin{array}{c}\text { Body mass } \\
\text { index } \\
\left(\mathrm{kg} \cdot \mathrm{m}^{-2}\right)\end{array}$} & \multirow[t]{2}{*}{$\begin{array}{c}\text { Smokers } \\
(\%)\end{array}$} & \multicolumn{2}{|c|}{$\begin{array}{l}\text { Menstrual cycle } \\
\text { (day of cycle) }\end{array}$} \\
\hline & Mean & SD & Mean & SD & Mean & SD & & Mean & SD \\
\hline $\begin{array}{l}\text { Exposed I }(\mathrm{N}=35) \\
\text { Exposed II }(\mathrm{N}=25) \\
\text { Referents }(\mathrm{N}=48)\end{array}$ & $\begin{array}{l}41.4 \\
42.9 \\
41.3\end{array}$ & $\begin{array}{l}6.0 \\
5.5 \\
6.5\end{array}$ & $\begin{array}{l}14.6 \\
16.2 \\
12.6\end{array}$ & $\begin{array}{l}4.9 \\
7.3 \\
5.4\end{array}$ & $\begin{array}{l}24.4 \\
24.4 \\
24.6\end{array}$ & $\begin{array}{l}4.8 \\
5.3 \\
3.7\end{array}$ & $\begin{array}{l}31.4 \\
50.0 \\
45.8\end{array}$ & $\begin{array}{r}10.3 \\
9.6 \\
10.3\end{array}$ & $\begin{array}{l}9.2 \\
8.4 \\
9.2\end{array}$ \\
\hline
\end{tabular}

Table 2. Urinary cobalt concentration of the plate painters and the referents.

\begin{tabular}{lcccc}
\hline \multirow{2}{*}{ Group } & \multicolumn{4}{c}{$\begin{array}{c}\text { Urinary cobalt/creatinine } \\
\left(\mu \mathrm{g} \cdot \mathrm{mmol}^{-1}\right)\end{array}$} \\
\cline { 2 - 5 } & Mean & $\mathrm{SD}$ & Range & P-value \\
\hline Exposed I $(\mathrm{N}=35)$ & 0.20 & 0.29 & $<0.007-1.50$ & 0.18 \\
Exposed II $(\mathrm{N}=25)$ & 1.17 & 1.18 & $0.02-4.90$ & $<0.0001$ \\
Referents $(\mathrm{N}=48)$ & 0.13 & 0.12 & $<0.0007-0.70$ & \\
\hline
\end{tabular}

registered as 0 ) at the time of the examination; smoking habits; duration of employment; and total number of years having worked with cobalt blue dyes. Weight and height were recorded.

The two subgroups of referents did not differ with respect to the background variables examined. The results reported were the same when the two cobaltexposed groups were compared with their respective referents. For simplicity we have therefore presented the referents as one group.

As shown in table 1, there were only minor differences between the cobalt-exposed individuals and the referents concerning age, body mass index, smoking habits, day of menstrual cycle, and percentage of preand postmenopausal women. The plate painters, especially the second exposure group, had been employed for a longer period than the referents. The duration of cobalt exposure did not differ from length of employment for the cobalt-exposed women.

Blood samples were drawn between 0900 and 1200 for the analysis of serum thyroxine $\left(T_{4}\right)$, 3,5,3'-triiodothyronine $\left(\mathrm{T}_{3}\right)$, thyroid stimulation hormone (TSH), and the $T_{3}$ resin uptake test $\left(\mathrm{T}_{3}\right.$ test). Serum $T_{4}$ and $T_{3}$ were measured by radioimmunoassay (8). Serum TSH was measured by immunoradiometric assay (Boots, Cell Tech, United Kingdom; lower detection limit $\left.0.05 \mathrm{mU} \cdot \mathrm{l}^{-1}\right)$. The $\mathrm{T}_{3}$ test was measured by an inhouse method (9). Estimates of serum free $T_{4}$ and free $T_{3}$ were obtained by multiplying serum $T_{4}$ and $T_{3}$, respectively, with the results of the $T_{3}$ test $\left(\mathrm{FT}_{4} \mathrm{I}, \mathrm{FT}_{3} \mathrm{I}\right)$.

The volume of the thyroid gland was determined by ultrasonography. The scanning procedure and volume calculation, as well as the accuracy and precision of the method, have been reported elsewhere $(10-12)$. In short, the method is based on recording crosssections through the gland at $0.5-\mathrm{cm}$ intervals. Each cross-section is outlined, and a computer program calculates the area of the section and the total thyroid volume. The precision of the ultrasonic method ranges between 5.1 and $7.8 \%$ in this range of thyroid volume (13), expressed as the coefficient of variation on double determination. The normal range is 9.6 to $27.6 \mathrm{ml}$ (11).

Urine samples were collected on Thursday afternoon (ie, after $4 \mathrm{~d}$ of work) and analyzed for cobalt content and creatinine. All of the urinary cobalt results were adjusted to the creatinine concentration. The urinary creatinine concentration was determined by the Jaffe reaction with a Beckman 42 spectrophotometer. The urinary cobalt concentration was estimated with a Zeeman atomic absorption spectrophotometer (lower detection limit $1.70 \mathrm{nmol} \cdot 1^{-1}$ ).

Each group of plate painters was compared with the referents with the use of unpaired t-tests and chi-square tests. For the correlation analysis the Spearman rank correlation test was used. All of the values assumed a two-tailed distribution. The level of significance was $5 \%$. The results from the t-tests were consistent with the results from the nonparametric Mann-Whitney rank sum tests.

\section{Results}

The results of the urine analysis are shown in table 2 . Exposed group I had almost normal levels of urinary cobalt corrected for creatinine, whereas group II had levels that were increased almost tenfold $(\mathrm{P}<0.0001)$.

No previous history of thyroid disease was found, except for one subject treated with $\mathrm{L}$ thyroxine after subtotal thyroidectomy due to Graves' disease. She was excluded from the study. There were no differences between the groups with regard to genetic disposition or the use of medicine, including oral contraceptives, vitamins, and herbal medicines (including those containing iodine).

The results concerning thyroid volume and function are listed in table 3. Group I (with levels of urinary cobalt almost as the referents) did not differ significantly from the referents in any of the variables. In contrast, group II (with increased levels of urinary cobalt) had increased serum $\mathrm{T}_{4}$ and $\mathrm{FT}_{4} \mathrm{I}$ levels $(\mathrm{P}=0.0001$ and 0.0029 , respectively), whereas the serum $\mathrm{FT}_{3} \mathrm{I}$ levels were marginally reduced $(\mathrm{P}=0.08)$. The thyroid volume tended to be lower in group II $(\mathrm{P}=0.14)$. 
Table 3. Thyroid volume and function of the plate painters and the referents. ( $T S H=$ thyroid stimulation hormone, $T_{4}=$ serum thyroxine, $\mathrm{FT}_{4} \mathrm{I}=$ free thyroxine, $\mathrm{T}_{3}=$ serum $3,5,3^{\prime}$-triiodothyronine, $\mathrm{FT}_{3} \mathrm{I}=$ free $3,5,3^{\prime}$-triiodothyronine)

\begin{tabular}{|c|c|c|c|c|c|c|c|c|c|c|c|c|c|c|c|c|c|c|}
\hline \multirow{2}{*}{ Group } & \multicolumn{3}{|c|}{$\begin{array}{c}\text { Volume } \\
(\mathrm{mil})\end{array}$} & \multicolumn{3}{|c|}{$\begin{array}{c}\text { TSH } \\
\left(\mathrm{mU} \cdot \mathrm{I}^{-1}\right)\end{array}$} & \multicolumn{3}{|c|}{$\begin{array}{c}\mathrm{T}_{4} \\
\left(\mathrm{nmol} \cdot \mathrm{I}^{-1}\right)\end{array}$} & \multicolumn{3}{|c|}{$\begin{array}{c}\mathrm{FT}_{4} \mathrm{I} \\
\text { (arbitrary U) }\end{array}$} & \multicolumn{3}{|c|}{$\left(\mathrm{nmol}^{\mathrm{T}_{3}} \cdot \mathrm{I}^{-1}\right)$} & \multicolumn{3}{|c|}{$\begin{array}{c}\mathrm{FT}_{3} \mathrm{I} \\
\text { (arbitrary U) }\end{array}$} \\
\hline & Mean & $\mathrm{SD}$ & $\begin{array}{c}\text { P. } \\
\text { value }\end{array}$ & Mean & SD & $\begin{array}{c}P . \\
\text { value }\end{array}$ & Mean & SD & $\begin{array}{c}P \text { - } \\
\text { value }\end{array}$ & Mean & SD & $\begin{array}{c}P . \\
\text { value }\end{array}$ & Mean & SD & $\begin{array}{c}P . \\
\text { value }\end{array}$ & Mean & SD. & $\begin{array}{l}P \text {. } \\
\text { value }\end{array}$ \\
\hline $\begin{array}{l}\text { Exposed I } \\
(N=35)\end{array}$ & 18.7 & 9.3 & 0.82 & 1.63 & 0.62 & 0.28 & 96.7 & 20.4 & 0.46 & 91.0 & 18.0 & 0.30 & 2.19 & 0.36 & 0.14 & 2.06 & 0.29 & 0.07 \\
\hline $\begin{array}{l}\text { Exposed II } \\
(N=25)\end{array}$ & 16.1 & 5.2 & 0.14 & 1.70 & 1.11 & 0.53 & 113.8 & 22.3 & 0.0001 & 97.8 & 13.5 & 0.0029 & 2.08 & 0.54 & 0.87 & 1.78 & 0.34 & 0.08 \\
\hline $\begin{array}{l}\text { Referents } \\
(\mathrm{N}=48)\end{array}$ & 19.2 & 9.3 & & 1.92 & 1.50 & & 93.6 & 17.6 & & 87.4 & 13.8 & & 2.06 & 0.40 & & 1.93 & 0.34 & \\
\hline
\end{tabular}

For the population as a whole (exposed and referents) there was no correlation between urinary cobalt (corrected for creatinine) and serum $\mathrm{FT}_{4} \mathrm{I}$ or thyroid volume [coefficient of multiple correlation $(R)=-0.03$ and $-0.03, P=0.74$ and 0.71 , respectively]. The same was true for exposed group II $(\mathrm{R}=0.31$ and -0.14 , $\mathrm{P}=0.16$ and 0.55 , respectively). There was no correlation between the duration of cobalt exposure (years) and thyroid volume for the population as a whole.

Smokers were found to have a significantly larger volume of the thyroid gland (mean 20.83 versus $16.52 \mathrm{ml}, \mathrm{P}=0.01$ ).

\section{Discussion}

The present study was cross-sectional and examined persons fit enough to work. Because of this "healthy worker" effect, the study may underestimate the health effects of cobalt exposure. However, the cobalt-exposed individuals had been employed significantly longer than the referents, and therefore it can be assumed that cobalt-exposed workers are not likely to quit their jobs more often than other workers.

In an earlier study $(14,15)$, using the same method for the analysis of cobalt among plate painters, a close correlation (coefficient $=0.82$ ) between the cobalt concentration of the blood and the urinary cobalt concentration was reported. Thus urinary cobalt is a reliable measure of the total uptake of cobalt by the blood.

In exposed group I the level of urinary cobalt corrected for creatinine did not differ significantly from the reference values, whereas a significantly higher level of urinary cobalt was found for group II. This difference in the level of cobalt excretion is possibly explained by the difference in the form in which cobalt is used at the two factories, namely, cobalt aluminate (group I, unchanged urinary cobalt) versus cobalt-zinc silicate (group II, increased urinary cobalt). There may be differences in the uptake and metabolism of the two forms, and accumulation of cobalt aluminate in the human body without excretion is also a possibility. It is known that the semisoluble form cobalt-zinc silicate is taken up from the lungs after inhalation and can be measured in blood and urine. The fate of the more insoluble cobalt aluminate in the lungs is not known.
However there were also some differences in the work process used to apply the cobalt-containing paint in the two factories, and these differences may account for the difference in the level of cobalt excretion. For clarity we have chosen to regard only group II as significantly exposed to cobalt.

The present study did not demonstrate any inhibitory effect of cobalt on thyroid function, and it did not suggest cobalt to be a goitrogen at the measured level of urinary concentration, which was almost tenfold that of the referents. In a previous study performed six years earlier at one of the factories (group II), the urinary cobalt concentrations of the exposed individuals were almost eightfold higher than in the present study $\left(8.35 \mu \mathrm{g} \cdot \mathrm{mmol}^{-1}\right.$ creatinine versus $1.17 \mu \mathrm{g} \cdot \mathrm{mmol}^{-1}$ creatinine), and no cases of goiter were found in the clinical examinations $(14,15)$. Thus we find it reasonable to conclude that cobalt exposure at the present level of exposure does not inhibit thyroid function or cause goiter in workers of porcelain factories. The inhibitory effect on iodine uptake and organification into the thyroid gland and the goitrogenic effect of cobalt known from the literature $(1-7)$ is probably only seen when cobalt is administered in much higher doses.

Smoking is known to be goitrogenic (12), and we did find an increased thyroid volume among smokers. Thyroid volume is also known to increase just before bleeding during the menstrual cycle (16). Essential criteria for the interpretation of the present clata therefore were that the different groups of subjects have an equal percentage of smokers and that the subjects were, on the average, at the same day of the menstrual cycle.

The present study did however demonstrate an effect of cobalt on thyroid hormone metabolism. Among the subjects with increased cobalt levels (group II), the mean serum levels of $\mathrm{T}_{4}$ and $\mathrm{FT}_{4} \mathrm{I}$ were significantly elevated ( 22 and $12 \%$, respectively), and the serum $\mathrm{FT}_{3} \mathrm{I}$ (but not serum $\mathrm{T}_{3}$ ) levels were marginally reduced. The serum TSH levels and thyroid volume were unchanged. This finding might be explained by a hitherto unknown effect of cobalt on the metabolism of thyroid hormones. Cobalt might inhibit the extrathyroidal 5'-deiodination of $T_{4}$ into $T_{3}$, which is of enzymatic nature, and create a "high $\mathrm{T}_{4}$-low $\mathrm{T}_{3}$ 
euthyroid state." A similar pattern is seen during treatment with the antiarrhythmic drug amiodarone, which has been demonstrated to inhibit hepatic and renal type-1 5'-deiodinase (17). However this mechanism of action is purely speculative, and further studies are needed to elucidate this possible effect of cobalt.

\section{Acknowledgments}

This study was supported by SID and Royal Copenhagen.

\section{References}

1. Kriss JP, Carnes WH, Gross RT. Hypothyroidism and thyroid hyperplasia in patients treated with cobalt. JAMA 1955;157:117-21.

2. Gross RT, Kriss JP, Spaet TH. The haematopoietic and goitrogenic effects of cobaltous chloride in patients with sickle cell anemia. Am Med Assoc J Dis Child 1954;88: 284-90.

3. Little JA, Sunico R. Cobalt-induced goiter with cardiomegaly and congestive failure. J Pediatr 1957;284-8.

4. Robey JS, Veazey PM, Crawford JD. Cobalt-induced myxedema. N Engl J Med 1956;255(20):955-7.

5. La Grutta A, Amato GM, Fedele S, Vitaliti S. Chronic cobalt poisoning: presentation of a clinical case of cardiomyopathy (abstract). Minerva Pediatr 1984;36:691-7.

6. Roche M, Layrisse M. Effect of cobalt on thyroidal $I$. J Clin Endocrinol 1956;16:831-3.

7. Pimental-Malaussena E, Roche M, Layrisse M. Treatment of eight cases of hyperthyroidism with cobaltous chloride. JAMA 1958;157(14):1719-24.

8. Kølendorf K, Møller BB, Rogowski P. The influence of chronic renal failure on serum and urinary thyroid hormone levels. Acta Endocrinol 1978;89:80.
9. Faber J, Kirkegaard C, Rasmussen B, Westh H, BuschSørensen M, Jensen IW. Pituitary-thyroid axis in critical illness. J Clin Endocrinol Metab 1987;65(2):315-20.

10. Rasmussen SN, Hjorth L. Determination of thyroid volume by ultrasonic scanning. J Clin Ultrasound 1974;2:143.

11. Hegedüs L, Perrild H, Poulsen LR, Andersen JR, Holm $\mathrm{B}$, Schnohr P, et al. The determination of thyroid volume by ultrasound and its relationship to body weight, age and sex in normal subjects. $J$ Clin Endocrin Metabol 1983;56:260-3.

12. Hegedüs L, Karstrup S, Veiergang D, Jacobsen B, Skovsted L, Feldt-Rasmussen U. High frequency of goitre in cigarette smokers. Clin Endocrinol 1985;22: $287-92$.

13. Hegdüs L, Karstrup S, Rasmussen N. Evidence of cyclic alterations of thyroid size during the menstrual cycle in healthy women. Am J Obstet Gynecol 1986;155:142-5.

14. Raffn E, Mikkelsen S, Altman DG, Christensen JM. Health effects due to occupational exposure to cobalt blue dye among plate painters in a porcelain factory in Denmark. Scand J Work Environ Health 1988;14: 378-84.

15. Mikkelsen S, Raffn E, Altman DG, Groth S, Christensen JM. Helbred og kobolt: Arbejdsmilijofondets forskningsrapporter [Health and cobalt: research report from the Foundation for Occupational Health]. Copenhagen: Arbejdsmiljmfondet, 1984. (English summary.)

16. Hegedüs L. Thyroid size determined by ultrasound: influence of physiological factors and non-thyroidal disease [dissertation]. Dan Med Bull 1990;37:24963.

17. Burger $A D$, Dinichert $D$, Nicot $P$, Jenny $M$, Lemarchand-Beraud T, Vallotton MB. Effects of Amiodarone on serum triiodothryronine, reverse triiodothyronine, thyroxine and thyrotropin. J Clin Invest 1976;58:255.

Received for publication: 22 July 1991 